\title{
Historical-philosophical aspects of professional communication in education management
}

\author{
[Historicko-filozoficke aspekty profesionalnej komunikacie \\ v manazmente vzdelavania]
}

\author{
Maria Pisonova - Peter Brecka - Viera Papcunova - Barbora Jaslovska
}

DOI: 10.18355/XL.2020.13.03.14

\begin{abstract}
The study deals with the implementation of historical and philosophical aspects of communication into the management process of an educational institution. The importance of this communication is often underestimated, even though it allows the manager to reflect on his communication mistakes. These communication mistakes are frequently causing inappropriate working climate, and it causes frequent changes in the jobs of employees. That all does not lead to the prosperity of the organization. Unfortunately, managerial communication is not sufficiently accepted in the training of school managers in Slovakia. This issue is included among the main subjects of the new study program at Constantine the Philosopher University in Nitra called Management of Education and Public Administration. The main goal of the new program is to prepare future managers of schools and school facilities for effective communication depending on the specific decision-making situation. The paper aims are to generalize several research findings of national and international authors who deal with the issue of managerial communication and its impact on current practice. The study answers questions related to philosophical aspects of communication from the theory of interpersonal relationships (behavioral, neoclassical theory), especially Rogers' theory of communication, which is based on the PCA (Person-Cantered Approach). The attention of the study is focused on some forms of managerial, mostly interpersonal communication such as effective telephone communication and conducting meetings, as well as communication bad habits and mistakes.
\end{abstract}

Key words: professional-managerial communication, historical and philosophical aspects of communication, communication theories, communication styles and techniques, education management

\begin{abstract}
Uvedená vedecká štúdia sa zaoberá implementáciou historicko-filozofických aspektov komunikácie do procesu riadenia vzdelávacej inštitúcie. Ich význam býva v praxi často podceňovaný napriek tomu, že umožňujú komunikátorovi - manažérovi reflektovat' svoje komunikačné chyby. Práve tie sú totiž častým dôvodom nevhodnej pracovnej klímy a následne fluktuácie zamestnancov, čo nevedie $\mathrm{k}$ prosperite organizácie. Žial' manažérska komunikácia nie je v príprave školských manažérov na Slovensku dostatočne akceptovaná. Aj preto je táto problematika zahrnutá medzi nosné predmety nového študijného programu na UKF v Nitre s názvom Manažment vzdelávania a verejnej správy. Jeho zámerom je, okrem iného, pripravit’ budúcich manažérov škôl a školských zariadení na efektívnu komunikáciu v závislosti na konkrétnej rozhodovacej situácii. Ciel'om príspevku je zovšeobecnenie viacerých výskumných zistení domácich a zahraničných autorov, ktorí sa zaoberajú problematikou manažérskej komunikácie a jej vplyvom na súčasnú realitu. Obsah vedeckej štúdie ponúka odpovede na otázky súvisiace s filozofickými aspektmi komunikácie a to z pohl'adu teórie medzil'udských vzt’ahov (behaviorálnej, neoklasickej teórie), ale najmä Rogersovej teórie komunikácie, ktorá vychádza z PCA
\end{abstract}

XLinguae, Volume 13 Issue 3, June 2020, ISSN 1337-8384, ISSN 2453-711X 
(Person Centred Approach). Pozornost' je upriamená na niektoré formy manažérskej, prevažne interpersonálnej komunikácie s akcentom na efektívnu telefonickú komunikáciu a vedenie pracovných porád, ako aj na komunikačné zlozvyky a chyby.

Kl'účové slová: profesionálna manažérska komunikácia, historické a filozofické aspekty komunikácie, teórie komunikácie, komunikačné štýly a techniky, manažment vzdelávania

\section{Úvod}

Komunikácia má svoju minulost', prítomnost' aj budúcnost' a to v zmysle kontextovom aj historickom. Kontext komunikácie je ovplyvnený dejom, ktorý sa odohral pred ňou a po nej. Historický aspekt súvisí s vývojom človeka od prvopočiatku až dodnes. V odbornej literatúre sa uvádza aj biologický, resp. fylogenetický aspekt komunikácie súvisiaci s vývojom človeka. Časové úseky medzi prvými dôležitými medzníkmi v komunikácii boli vel'mi dlhé, ale postupne sa skracovali. Prvá zmienka o existencii jazyka je známa z doby 10000 rokov pred Kristom. Najstaršia zachovaná písomná správa pochádza z roku 4000 rokov pred Kristom. Guttenberg vynašiel tlač v roku 1450 a v roku 1837 bol vytvorený telegraf Morse. Neskôr, v roku 1844 sa podarilo odoslat' prvú správu telegrafom a o pár rokov neskôr aj prostredníctvom telefónu. V minulom storočí pokračoval komunikačný progres vynájdením rozhlasu, televízie, satelitov, počítačov, internetu, intranetu, digitalizáciou písomných, obrazových informácií, čo pokračuje závratnou rýchlost'ou až dodnes. Je zrejmé, že interpersonálna komunikácia prežíva $\mathrm{v}$ súčasnosti krízu napriek tomu, že jej význam je nespochybnitel'ný. Verbálna komunikácia je totiž jedna zo základných schopností človeka, ktorá mu umožňuje výmenu informácií, nadväzovanie vzt’ahov, riešenia konfliktov, vyjadrovanie emócií, či vyjednávanie, riadenie procesov nevynímajúc.

\section{Historické východiská manažérskej komunikácie}

Komunikácie je teda základný interakčný nástroj, ktorý je typický pre človeka ako spoločenskú bytost'. Spôsob komunikácie sa pochopitel'ne, postupom času menil, pretože ju ovplyvňovali mnohé faktory. V staroveku sa l'udia pod vplyvom sofistiky často považovali za „sofistikované osobnosti“, čo znamenalo, že sú výrazne orientovaní na formálnu stránku prejavu s ciel'om vzbudit' dojem vzdelaného človeka, ktorý sa vie predovšetkým vyjadrovat' teatrálnym spôsobom. Pre tento komunikačný prístup je príznačný fakt, že komunikátor často nevie odpovedat' na otázky. Zároveň je ale potrebné uviest', že ide o vhodný prostriedkom pre zdokonal'ovanie výrečnosti. V súčasnosti sa pojem sofistika používa v súvislosti s kultivovaným, náročným a komplikovaným komuniké (Mikuláštík, 2003). Pojem eristika, ktorý tiež pochádza z obdobia staroveku, ale na rozdiel od sofistiky akcentuje umenie viest' spory (napr. usvedčit', porazit' protivníka) a docielit' vít'azstvo. V porovnaní so sofistikou, ktorej zámerom bolo presvedčit' poslucháča o svojej pravde, eristi sa snažili o múdry prejav, z ktorého je zrejmé, že komunikovanej problematike poslucháči rozumejú. Z uvedeného príkladu je zrejmý obsahový a vzt'ahový aspekt, ktorý sa uplatňuje aj v súčasnosti. Na obsahovej úrovni komunikácie sú artikulované informácie predovšetkým sémantického charakteru. $\mathrm{Na}$ vzt’ahovej úrovni komunikácie sú vyjadrené afektívne relácie medzi komunikujúcimi a vzt'ahy $\mathrm{k}$ tematickému obsahu komunikácie na neverbálnej úrovni pomocou výrazových prostriedkov, tj. mimikou, gestikou, paralingvistickými aspektami reči. (Svancara, 1999). Ako uvádzajú (Petrova - Kozarova, 2018: 117): „Komunikácia vysvetl’uje vzt’ahy medzi mozgovými a jazykovými štruktúrami, teda ako sa správa jazykový systém v mozgu človeka (lokalizácia a aktivácia jazykových reprezentácií v mozgu člověka), nakol'ko jazyk je abstraktnou záležitost'ou konceptu mysle. Navyše jazykové regióny mozgu sú špecializované - najmä pre jednotlivé reprezentácie symbolickej komunikácie.“ 
Termín komunikácia pochádza $\mathrm{z}$ latinského communicare $=$ styk, prenášanie informácii. Na komunikácii sa podiel'ajú viacerí činitelia. (Szarková, 1996) medzi nich zarad'uje emitenta, teda odosielatel'a informácie a jeho protipól percipienta (prijímatel'a informácie). Komunikácia medzi týmito dvoma aktérmi môže byt' čiastočná a úplná. Ak percipient prijme informáciu od odosielatel’a a spätne na ňu reaguje, jedná sa o úplnú sociálnu komunikáciu. Pokial' správa od odosielatel'a ostane bez odozvy, prípadne ju adresát ani neprijal, hovoríme o čiastočnej komunikácii. Uvedené tvrdenie dopín̆a (Petrufova et al., 2009), ktorí uvádzajú, že v praxi sa často používajú pojmy ako komunikátor (ten, kto vysiela správu), komunikant (prijímatel' vyslanej správy), komuniké (konkrétna správa, ktorú komunikátor vysiela). Táto správa je posielaná cestou, ktorá sa volá komunikačný kanál. (Petrufová et al., 2009). Tieto poznatky priniesla kybernetika, pre ktorú je okrem iného dôležité kódovanie a dekódovanie správ, ako aj ich časové parametre. O rozvoj a poznanie komunikácie sa významným spôsobom pričinila aj psychológia, pre ktorú nie je komunikácia iba nástrojom prenosu informácií medzi odosielatel'om a prijímatel'om, ale aj prostriedkom na vyjadrovanie postojov k predmetu, ku komuniké, či k príjemcovi informácie nevynímajúc rôznu úroveň sebaprezentácie, sebapotvrdzovania, ovplyvňovania či ul'ahčovania vzájomného porozumenia. Je všeobecne známe, že človek komunikuje s okolím, aj ked' nevyužíva verbálne výrazové prostriedky. Existuje niekol'ko definícií pojmu komunikácia, ale všetky sa zhodujú v nasledovných charakteristikách (Konvit - Jakubikova, 2008: 58): „Komunikácia v širšom slova zmysle predstavuje interakciu medzi dvomi alebo viacerými objektmi, ktorej ciel'om je odovzdanie, resp. získanie určitej správy.“

\section{Vplyv teórie medzil'udských vzt’ahov (behaviorálnej, neoklasickej teórie) na rozvoj manažérskej komunikácie}

V súčasnosti existuje niekol'ko teoretických a filozofických prístupov, ktoré majú $\mathrm{v}$ procese komunikácie svoj význam. Nie všetky z nich sú ale využitel'né v riadiacej praxi aj ked' niekol'ko prvkov našlo svoje uplatnenie, napríklad zrkadlenie - pacing, reframing, interpretácia spôsobov prenosu a d’alšie. (Mikluláštík, 2006). Profesionálne riadenie vzdelávacej inštitúcie je závislé od kvalitnej manažérskej komunikácie, ktorej úlohou je konsolidácia a budovanie medzil'udských vzt'ahov a zároveň dosahovanie kvalitných pracovných výsledkov. Dôsledkom zlyhania tejto dôležitej schopnosti manažéra je nedostatočný prenos informácií, ktorý spôsobuje na pracovisku zhoršenie medzil’udských vzt’ahov, nárast fluktuácie zamestnancov a pochopitel'ne pokles kvalitatívnej úrovne školy. $\mathrm{Na}$ túto požiadavku upozornili predstavitelia teórie medzil'udských vzt’ahov (behavioristickej, neoklasickej teórie) ešte v minulom storočí. M. P. Follettová, E. Mayo, T. N. Whitehead, F. J. Roethlisberger a neskôr A. Maslow a D. McGregor už v tom období apelovali na uplatňovanie psychologicko- sociálnych prístupov k zamestnancom. Upriamovali svoju pozornost' predovšetkým na l'udské komponenty a v tomto zmysle na skúmanie psychologických motívov správania sa l'udí v pracovnom procese, skupinové vzt’ahy a normy, problémy konfliktu a spolupráce, štýly vedenia l'udí, neformálnu organizáciu a v neposlednom rade na komunikáciu a komunikačné bariéry (Sedlák, 2007).

\section{Kongruentné rozhodovanie $v$ intenciách filozofie PCA (Person Centred Approach) C. R. Rogersa}

Na uvedený problém upozornil ako jeden z prvých C. R. Rogers vo svojich knihách „Moc bytia“, „Túžba po osobnej moci“ a v d’alších. Pojem kongruencia predstavuje súlad medzi prežívaním a uvedomovaním si, príp. medzi prežívaním, uvedomovaním a komunikáciou. (Sollarova, 2005: 116) tvrdí nasledovné: „Z pojmu kongruencia vyplýva dôsledok, že ak je jedinec úplne kongruentný, ak sa jeho fyziologické prežívanie presne odráža vo vedomí a jeho komunikácia presne zodpovedá jeho 
uvedomovaniu, tak potom jeho komunikácia nikdy nemôže obsahovat' vonkajší efekt.“ V inom vyjadrení to znamená, že ak je človek naozaj kongruentnou osobnost'ou, potom je jeho komunikácia vyjadrená v kontexte jeho osobného vnímania. Prevažná čast' vlastnej organizácie školského manažéra spočíva v kontrole pracovného zat’aženia. Ak na všetky požiadavky, s ktorými sa riaditel' školy stretne odpovie ,áno“, je to signál príznačný pre permanentné pret’ažovanie a stres. Navyše sa môže stat', že neustále riešenie menej dôležitých úloh mu zabráni plnit' úlohy klúčového významu. Častými príčinami prejavu súhlasu riaditel’a školy proti vlastnej vôli a presvedčeniu sú nasledovné dôvody: verí tomu, že odmietnut' je sebecké; ostatní od neho očakávajú, že bude súhlasit'; obavy, že osoba, ktorú riaditel' odmietne sa bude cítit' nepríjemne; myslí si, že je nezdvorilé odmietnut'; cíti sa previnilo; myslí si, že by nebol oblúbený/á a pod. Na základe odporúčania B. Uhliga (2008) sme formulovali tri tvrdenia, ktoré by mohli riaditel'ovi školy pomôct' vyjadrit' zamietavé stanovisko: čas riaditel'a je rovnako cenný, ako čas kohokol'vek iného; riaditel' školy má právo požiadavku odmietnut' a niest' zodpovednost' za prípadné následky; je potrebné si uvedomit', že pri vyjadrení odmietavého stanoviska nejde o odmietnutie človeka, ale jeho požiadavky. Spôsob odmietnutia závisí od typu temperamentu a ostatných osobnostných rysov toho - ktorého riaditel'a školy. Z uvedeného dôvodu J. Caunt (2007) určil nasledovné tri prístupy k odmietnutiu požiadavky: agresívny, bojazlivý a asertívny typ. Úspešné riešenie uvedenej situácie je podmienené fenoménom skupinovej súdržnosti, ktorá je založená na emocionálnom základe vo vzt'ahoch medzi členmi skupiny. Skupinovú súdržnost' možno vyjadrit' pojmom konsenzus. „Konsenzus predpokladá vznik zhodných orientácií u členov skupiny vo vzt’ahu k určitým pre skupinu významným hodnotám." (Armstrong - Stephen, 2008: 26; Cf. Ibragimova et al., 2020). V inom vyjadrení to znamená, že na základe konsenzu vzniká v pracovnej skupine psychologická zhoda a efektívna komunikácia. Pri dosahovaní tohto efektu je možné iniciovat' vznik skupinových noriem, ktoré predpokladajú: určenie jasných pravidiel, ktoré platia pre všetkých členov pracovnej skupiny rovnako (napr. pre riaditel'a a ostatných zamestnancov školy); vytvorenie mechanizmov sociálnej kontroly (pri konsenzuálnom prijatí pravidiel spravidla dochádza ku vzájomnej, spontánnej a nedirektívnej kontrole ich dodržiavania) a definovanie sankcií za porušenie pravidiel. V aplikácii na školskú riadiacu prax možno sociálne skupinové normy konkretizovat' ako určenie pravidiel a zásad, ktoré sa vzt’ahujú na všetkých zamestnancov školy. Uvedený spôsob spolupráce vytvára podmienky na budovanie vhodnej klímy školy, ktorá eliminuje porušovanie pravidiel, ale najmä vytvára podmienky na to, aby riaditel' školy nemusel komunikovat' zamietavé stanovisko k neoprávneným požiadavkám svojich spolupracovníkov.

V prípade, ak riaditel' školy aj napriek vyššie uvedeným opatreniam bude musiet' povedat' „nie“, je žiaduce, aby dodržal niekol'ko zásad. V časovom manažmente ide o požiadavku vyjadrit' zamietavé stanovisko prostredníctvom tzv. kongruentnej správy, ktorá sa dá naučit' a trénovat'. Úspešnost' jej osvojenia je pri tom do značnej miery závislá od schopnosti riaditel'a školy facilitovat' osobnú zmenu prostredníctvom tzv. mäkkých zručností (soft skills), ktoré po prvýkrát definoval C. R. Rogers, zakladatel' humanistickej psychológie a indirektívnej psychoterapie. Ich princíp pútavou formou vyjadril $\mathrm{v}$ mnohých jeho knihách napr. O osobnej moci Rogers (1999), Způsob bytí Rogers (1998), Klientom centrovaná terapia Rogers (2000) a v d'alších. V slovenských vedeckých a akademických kruhoch pôsobí ako pokračovatel'ka na človeka zameraného (centrovaného) prístupu - PCA prof. PhDr. Eva Sollárová, CSc. K tejto tematike napísala knihu s názvom: Aplikácie prístupu zameraného na človeka (PCA) vo vzt’ahoch (Sollarova, 2005) a preložila monografiu Roberta J. Sternberga - pokračovatel'a myšlienok C. R. Rogersa s názvom: Prečo robia múdri l'udia hlúposti?

Kongruencia umožňuje riaditel'ovi školy byt' jedinečnou, autentickou osobnost'ou, ktorá dobre pozná svoje silné a slabé stránky a na základe toho dokáže pomerne 
presne určit' svoje možnosti a ciele. Riadiaci zamestnanec týchto kvalít je spôsobilý vyslat' smerom k svojmu okoliu spomínanú kongruentnú správu, ktorej charakter eliminuje pri komunikácii odmietavého stanoviska pravdepodobnost' defenzívnej reakcie iného človeka. Podmienkou dosiahnutia vyššie uvedeného efektu je, aby riaditel' školy posúdil požiadavku, tzn. položil si tieto otázky: Je požiadavka z môjho pohl'adu akceptovatel'ná, reálna a sledovatel'ná v čase? Je to moja priorita? Chcem to urobit? Aké by boli následky jej odmietnutia? Som schopný/á prijat' (akceptovat') tieto následky? Kongruenciu možno v tomto zmysle považovat' za životnú filozofiu, ktorá umožňuje riaditel'ovi školy odstránit' časový stres a budovat' efektívne komunikačné vzt’ahy so svojimi spolupracovníkmi aj v prípade, ak sú jeho názory v rozpore s ich predstavami. Komunikácia kongruentnej správy, ktorá vyjadruje zamietavé stanovisko je často podmienená zvnútornením filozofie PCA (Person Centred Approach) a tréningom. Efektívna tímová práca je determinovaná osvojením si techniky „kongruentnej správy“, ktorej základné piliere upravila (Pisonova, 2012) podl'a (Sollarova, 2005) nasledovne: komunikácia svojho odmietavého stanoviska v prvej osobe jednotného čísla (neskrývat' sa za niekoho iného - stát' si za svojim rozhodnutím); svoje stanovisko vyjadrovat' prostredníctvom vlastných pocitov (napr. necítim sa dobre v tejto situácii..., mám záujem o vyriešenie tohto problému..., dotklo sa ma Vaše vyjadrenie... a pod.); partnera neosočovat', neurážat' a neponižovat'. (napr. Čo si o sebe myslíte...!, Vy sa nebudete „vozit““ na mojej dcére...!, Ja Vám ukážem...! a pod.); neustále držat' v rukách „kormidlo“, t.j. nenechat' sa zatlačit’ do úzadia; používat' vecnú argumentáciu založenú na faktoch a podložených tvrdeniach. Príjemným dôsledkom zvládnutia techniky odmietnutia je, že riaditel' školy už nebude musiet' klamat', vyhovárat' sa a cítit' sa previnilo. Práve naopak, týmto spôsobom docieli vecnejšiu komunikácia so svojimi zamestnancami, bude rešpektovaný pre svoju úprimnost' a transparentnost', bude mat' viac času na svoje priority a väčšiu kontrolu nad svojim životom.

\section{Profesionálna komunikácia v podmienkach riadenia vzdelávacej inštitúcie}

V starom Grécku a Ríme bola schopnost' komunikácie nevyhnutnou požiadavkou vtedajšej spoločnosti rovnako ako za čias Sokratesa, Platóna, či Aristotelesa. V súčasnosti je charakteristikou moderného sociálneho rozvoja rastúca sila komunikačných prostriedkov, teoretických poznatkov a informačných technológií. (Rodriguez et al., 2015). Intelektuálna kultúra je chápaná (Pushkarev - Pushkareva, 2017) ako kultúra spoločnosti, hromadenie, reprodukcia a vytváranie špeciálnych informácií vo forme systému hodnôt (nápady, ideály, tradície, formy a normy komunikácie a správania, atd’.), ako osobitné prostredie pre rozvoj spoločnosti. V tejto súvislosti sa stále častejšie označuje súčasná škola ako moderná súčasná škola, činná škola 21. storočia alebo škola pre život. Napriek tomu $\mathrm{v}$ posledných rokoch zaznamenávame rastúcu kritiku postupov, komunikácie, metód a stratégií, prostredníctvom ktorých pedagógovia svojim žiakom sprostredkúvajú obsahy vzdelávania. Moderná filozofia edukácie sa pri tom intenzívne zameriava na procesuálnu, tvorivú, činnú a kognitívnu koncepciu vyučovania. (Duchovicova Fenyvesiova, 2019).

Profesionálna komunikácia vzniká a používa sa v presne určenom prostredí, má presne definovaný obsah, o čom vypovedajú aj zvolené výrazové prostriedky a komunikačné postupy, je teda vždy cielená. (Majtan et al., 2003). Jej hlavným znakom je používanie určitých konkrétnych termínov, ktoré dávajú zmysel iba $\mathrm{v}$ istých súvislostiach, tým pádom môže byt' pre l'udí, ktorí do daného problému nie sú zainteresovaní, nezrozumitel'ná. Uvedený autor definuje profesionálnu komunikáciu nasledovne: použiva sa v nej odborná terminológia a špecifické výrazové prostriedky; prevažuje $\mathrm{v}$ nej jasné definovanie komunikačného zámeru; vyznačuje sa stupňom záväznosti voči prijímatel'om informácie; vyznačuje sa taktiež spôsobom riešenia

XLinguae, Volume 13 Issue 3, June 2020, ISSN 1337-8384, ISSN 2453-711X 
prípadných komunikačných problémov. Schopnost' komunikovat' profesionálne je jednou zo základných požiadaviek každého manažéra, riaditel'a vzdelávacej inštitúcie nevynímajúc. Tento pojem zaviedol do teórie manažmentu (McQuail, 2007). Charakterizuje ho ako špecifický typ komunikácie, ktorá na rozdiel od všeobecnej sociálnej komunikácie vzniká a používa sa v určitom presne definovanom prostredí, nielen podnikatel'skom. Manažérska komunikácia je obsahovo vyprofilovaná. Typické sú pre ňu komunikačné nástroje, postupy a prostriedky, ktoré komunikátor a komunikant musia v komunikačnom procese rešpektovat' (Szarkova, 2018). Vel'mi často sa $\mathrm{v}$ praxi spája pojem manažérska komunikácia s procesom riadenia podniku. Avšak manažérsku komunikáciu musia na požadovanej úrovne uplatňovat’aj riaditelia škôl, či školských zariadení, ako aj ich zástupcovia, respektíve stredný a nižší manažment. V tomto kontexte je ale opät' potrebné dodat', že uvedené spojenie existuje aj medzi riaditel'om školy a učitel'om, či zákonným zástupcom žiaka a pod. V každej činnosti manažéra sa kladie mimoriadny dôraz na efektívnu interpersonálnu komunikáciu. Manažéri permanentne poskytujú informácie, ktoré musia byt' pochopené správne. Z uvedeného dôvodu je spôsob, akým ich komunikujú vel'mi dôležitý. (Donnelly et al., 1997) za týmto účelom definovali štyri oblasti informácií, ktoré aktéri rozhodovacích aktov bud' poznajú, alebo nepoznajú. V aplikácii na školskú riadiacu prax ide o ich nasledovnú charakteristiku. Oblast', ktorá v najväčšej miere prispieva k efektívnej interpersonálnej komunikácii nazvali „aréna“. V tomto prípade sú komunikátorovi - manažérovi školy aj príjemcovi - zamestnancom školy známe všetky relevantné informácie, nevyhnutné k vedeniu efektívnej vzájomnej komunikácie. Jej súčast'ou je spoločné zdiel'anie pocitov, údajov, názorov a schopností, čo predpokladá vzájomné porozumenie. „Hluchý priestor“ vzniká vtedy, ak príslušné informácie majú zamestnanci školy, ale nie jej vedenie. V tejto súvislosti je jeden $\mathrm{z}$ aktérov $\mathrm{v}$ nevýhode, čím sa komunikácia stáva kontraproduktívnou. Opačný efekt spôsobuje situácia, ak vedenie školy disponuje potrebnými informáciami, ale v prípade zamestnancov školy absentujú. Tento stav autori nazvali „fasáda“. Fasáda rovnako ak hluchý priestor zmenšujú arénu a eliminujú predpoklad efektívnej komunikácie. Posledná oblast' má názov „neznámo“. Predstavuje prípad, ked’ nedostatkom relevantných informácí́ trpí nielen vedenie školy, ale aj jej zamestnanci. Tí, ktorí chcú efektívne komunikovat' môžu použit' nechránené polohy, alebo spätnú väzbu. Avšak v skutočnosti nie sú manažéri vždy schopní použit' obidve tieto metódy. V uvedenej súvislosti (Donnelly et al., 1997) definovali štyri manažérske štýly, respektíve typy. Typ A je príznačný pre manažérov, ktorí nepoužívajú ani nechránené polohy, ani spätnú väzbu. Väčšinou sú úzkostliví, nepriatel'skí a autokratickí. Pokial riadia školu, či inú vzdelávaciu inštitúciu manažéri typu A, je možné očakávat' neefektívnu interpersonálnu komunikáciu a stratu individuálnej tvorivosti zamestnancov školy. Typ B predstavujú manažéri, ktorí túžia po kvalitných vzt’ahoch so svojimi zamestnancami, ale kvôli vlastným postojom nie sú schopní vyjadrit' svoje pocity a názory. Z uvedeného dôvodu nemôžu používat' nechránené polohy a musia sa spoliehat' na spätnú väzbu. Dôsledkom uvedeného stavu je skutočnost', že zamestnanci školy nebudú uvedenému typu manažérov dôverovat', pretože si svoje nápady a názory nechávajú iba pre seba. Správanie sa podl'a typu B je vlastné manažérom, ktorí chcú praktikovat' niektorú formu permisívneho vedenia, t.j. ponechávajú veciam vol'ný priebeh, alebo prejavujú nezáujem o riešenie rôznym problémov. Manažéri, ktorí vysoko pozitívne hodnotia svoje vlastné nápady a názory, ale nie invenciu a vklad ostatných zamestnancov, používajú nechránenú polohu na úkor spätnej väzby. Tento prístup je typický pre manažérov typu $\mathrm{C}$, dôsledkom čoho je takmer neexistujúca komunikácia so zamestnancami. Najefektívnejším komunikačným štýlom je ten, ktorý vyváženým spôsobom uplatňuje nechránené polohy a spätnú väzbu. Ide o manažérov typu $\mathrm{D}$, ktorí sú ochotní prijímat' spätnú väzbu, ale aj vyjadrovat' svoje pocity, čiže sú autentickí. $\mathrm{Na}$ základe charakteristík vyššie uvedených typov možno konštatovat', že 
rozhodujúcim faktorom, ktorý determinuje efektívnost' interpersonálnej komunikácie je interpersonálny štýl, teda postoj manažérov k nechránenej polohe a spätnej väzbe. Často sa stretávame v praxi s informáciami, ktorých je pomerný dostatok, aktéri im bud' nerozumejú, alebo sú neobjektívne. Uvedená situácia môže nastat' vo vzdelávacej inštitúcii, kde sa delegujú kompetencie nie podl'a osobnostných charakteristík pedagógov, ale náhodne. Príčinou nesprávnej komunikácie je vel'mi často skutočnost', že riaditel' školy či školského zariadenia nepozná preferenciu profesionálnych typov pedagogických zamestnancov. Tie už v roku 1966 zadefinoval (Suler, 2002). Ciel'om jeho snaženia bolo určenie kariérnej orientácie zamestnanca, respektíve jeho preferovaných štýlov a kariérneho konfliktu. Od týchto informácií totiž závisí výber adekvátnych komunikačných štýlov a pridel'ovanie primeraných pracovných úloh zamestnancom. Zistil, že l'udia majú sklon uprednostňovat' prostredie, ktoré zodpovedá ich povahovej orientácii a preto určil šest' typov osobností podl'a profesionálneho prostredia. Každý z nich orientuje svoju kariéru, resp. výber povolania do pracovného prostredia, ktoré je $\mathrm{v}$ súlade $\mathrm{s}$ jeho osobnostnou preferenciou. Typ realistický sa vyznačuje schopnost'ami a zručnost’ami spojenými s fyzickou aktivitou (pol'nohospodárstvo, remeselníctvo a pod.). Typ skúmavý dáva prednost' poznávacím aktivitám (premýšl’anie, analyzovanie) pred emocionálnymi aktivitami (biológia, matematika, kybernetika, geológia). Typ sociálny preferuje interpersonálnu aktivitu pred intelektuálnou alebo fyzickou aktivitou (sociálna práca, diplomacia, psychologické poradenstvo, učitel'stvo). Typ konvenčný vyhl'adáva činnosti jasne vymedzené pravidlami; rád vykonáva príkazy nadriadených; záujmy organizácie môžu byt' pre neho dôležitejšie ako vlastné potreby (účtovníctvo, financovanie). Typ podnikavý využíva svoje schopnosti k získavaniu ostatných a vedie ich $\mathrm{k}$ dosiahnutiu svojich ciel'ov (manažment, právo, obchod). Typ umelecký sa usiluje o sebavyjadrenie, vyjadrenie svojich pocitov a tvorivej práce (hudba, výtvarné umenie, herectvo). Pokial' jeden typ výrazne prevažuje, je profesionálna orientácia človeka v podstate jednoduchá. Pokial' však dochádza k rovnováhe dvoch alebo viacerých záujmov, nastáva u človeka kariérny konflikt (napríklad pri riešení pracovnej úlohy), pri čom v priebehu d'alšej práce sa budú potlačené varianty znovu pripomínat'. Správny výber komunikačného štýlu determinujú aj základné tímové roly zamestnancov školy, ktoré v roku 1981 určil na základe mnohých výskumov (Suler, 2002). Uviedol, že podmienkou kvalitnej tímovej práce je uplatňovanie komunikačného štýlu, selektovaného na základe určenia prínosu pre tím, ako aj nedostatkov a nebezpečenstva vyplývajúcich $\mathrm{z}$ deviatich tímových rolí: inovátor, hl'adač zdrojov a príležitostí, koordinátor, formovač, pozorovatel' (vyhodnocovač), stmel'ovač, realizátor, dokončovatel' a špecialista. Výsledky výskumov, ktoré sa realizovali na Univerzite Konštantína Filozofa v Nitre (Pisonova et al., 2014) s ciel'om zistit' preferovanú tímovú rolu u riaditel'ov základných škôl na Slovensku poukázal na nerovnomernost' ich zastúpenia v učitel'ských kolektívoch. Výrazne dominujú stmel'ovači, pri čom absentujú inovátori, realizátori a dokončovatelia. Pri tomto rozložení je realizácia interpersonálnej komunikácie vel’mi náročná a často neefektívna.

\section{Komunikačné štýly a techniky $\mathbf{v}$ manažmente vzdelávania}

Výsledky prezentovaného výskumu možno zohl'adnit' pri implementácii komunikačných techník v procese riadenia vzdelávacích inštitúcií. Ich využitie v praxi bolo predmetom skúmania procesu komunikácie najmä začiatkom 20. storočia za účasti odborníkov pracujúcich najmä $\mathrm{v}$ týchto vedných odboroch: filozofia, sociológia, psychológia, psycholingvistika, manažment a pedagogika.

Je dôležité, aby manažér bol schopný efektívne komunikovat' so všetkými zamestnancami školy. V závislosti na ich osobnostných charakteristikách (Robbins, 1992) rozlišuje štyri základné komunikačné štýly: analytický, riadiaci, priatel'ský 
a expresívny. Analytická osobnost' má sklon k premýšl’aniu, pomalému konaniu, častej kontrole a k pasivite. Riadiaca osobnost' je aktívna, ambiciózna, nezávislá, vytrvalá, opatrná, vyhl'adáva sút'aže a konflikty a je rezervovaná v prejave svojich citov. Opakom riadiacej osobnosti je priatel'ská osobnost', ktorá sa vyznačuje citlivostou, rada teší ostatných spolupracovníkov, má pre l'udí pochopenie a má úprimnú radost' z ich úspechov. Expresívna osobnost' je tiež citlivá, má rada vzrušenie a sklony $\mathrm{k}$ unáhlenému zovšeobecňovaniu na rozdiel od priatel'ských osobností je však egocentrická. V zmysle uvedených charakteristík by mal každý riadiaci zamestnanec poznat' predpoklad kompatibilných a toxických vzt'ahov. Kompatibilné väzby sú príznačné pre kombináciu analytickej a riadiacej osobnosti, analytickej a priatel'skej osobnosti, ako aj priatel'skej a expresívnej osobnosti, respektíve zamestnanca školy. Toxické vzt’ahy predstavuje spojenie analytického a expresívneho zamestnanca, riadiaceho a expresívneho zamestnanca a napokon spojenie medzi riadiacim a priatel'ským zamestnancom.

V manažérskej praxi sa používajú špecifické typy komunikácie, ktoré sa uplatňujú v závislosti od situácie, ktorú manažér rieši. Medzi najčastejšie použivané patria: vyjednávanie (negociačné techniky), lobizmus, koučovanie a obchodné rokovanie (Majtan et al., 2016).

Vyjednávanie môže prebiehat' $\mathrm{v}$ školskej riadiacej praxi ako špecifická forma interpersonálnej komunikácie v malej skupine alebo ako forma masovej komunikácie. Zmyslom a ciel'om vyjednávania je dosiahnut' dohodu, optimálne má konsenzus prednost' pred kompromisom (Pisonova et al., 2014). Lobizmus (lobbing) predstavuje účelové sprostredkúvanie informácií o záujmoch školy s ciel’om dosiahnut' jej prospech. V súčasnosti je lobizmus považovaný za legálny nástroj školského marketingu (Svetlik, 1996). Jeho opodstatnenie stúpa hlavne, ked’že konkurencia medzi školami, ako aj dopyt po kvalitnej vzdelávacej službe narastá. (Pisonova, 2011). Koučovanie (koučing) je jeden z najnáročnejších typov manažérskej komunikácie. Je zameraná na poradenskú komunikáciu s celou škálou komunikačných poradenských prostriedkov a techník. Ich súčast’ou je napríklad priama diskusia, cielený štruktúrovaný rozhovor s uplatnením empatie, rozpoznania a vyjadrenia pocitov a objektívnosti, ako aj poskytovanie a prijímanie spätnej väzby. $\mathrm{V}$ praxi sa často zamieňa pojem koučing a mentoring. „Mentoring je pravdepodobne najlepší spôsob ako si osvojit' konkrétne poznatky a zručnosti potrebné k výkonu svojej práce. Je doplnený o formálny výcvik, ktorým poskytuje mentor zamestnancovi vlastné skúsenosti v dlhšom časovom horizonte“. (Armstrong, 2015). Základom mentoringu je spolupráca medzi mentorom a mentorovaným zamestnancom (mentee). Jeden zo základných rozdielov medzi koučingom a mentoringom spočíva $\mathrm{v}$ tom, že mentor komunikuje svoje vlastné pohl'ady na riešenie situácie, zatial' čo kouč komunikuje riešenia iných l'udí, z rôznych uhlov pohl'adu. (Petrasova et al., 2014). V tomto prípade je komunikácia so zamestnancom náročnejšia, nakol'ko v nej ide často o facilitáciu osobnostnej zmeny a postojov, čo je dlhodobý proces.

V procese uplatňovania adekvátnej manažérskej komunikácie by mal manažér školy venovat' pozornost' aktívnemu počúvaniu, kladeniu otázok, testovaniu porozumenia, sumarizovaniu a uplatňovaniu mlčania. (Suler, 2002). Ked’že ide o pomerne rozsiahlu problematiku, upriamime pozornost' na aktívne počúvanie, ktoré sa v školskej riadiacej praxi uplatňuje zriedkavo, v niektorých prípadoch vôbec. Zásady aktívneho počúvania je nevyhnutné dodržiavat' najmä pri riešení konfliktov na pracovisku. Ich rešpektovanie je podmienené prejavmi pozornosti, primeranými reakciami na hovoriaceho a efektívnym vyhodnocovaním prezentovaného obsahu, či pocitov zamestnanca. Poslucháč (riaditel', či zástupca školy) by sa mal snažit' sústredit' na prejav, eliminovat' myšlienkovú neprítomnost', sledovat' gestá hovoriaceho a dávat' najavo svoju pozornost' komuniké zamestnanca. V manažérskej komunikácii má aktívne počúvanie dvojaký význam (Borg, 2007): optimalizuje komunikačnú situáciu medzi komunikantmi (utvára podmienky na partnerský komunikačný vzt’ah) 
a napomáha získat' v komunikačnom procese také informácie, ktoré by manažér získal inou cestou s problémami. Fázy aktívneho počúvania (Szarkova, 2018) definuje nasledovne. Prvú fázu fyzikálneho počúvania tvorí miera schopnosti presne zachytit', identifikovat' a analyzovat' v pocitovej a vnemovej rovine systém vysielaných verbálnych a neverbálnych znakov a signálov. Druhá fáza spracovania získaných informácií sa sústred’uje na triedenie, analýzu a syntézu prijatých signálov a informácií, na ich posudzovanie vo vzt'ahu k vnútorným hodnotám a vonkajším podmienkam komunikačného procesu. Tretia interpretačná fáza je založená na predpoklade vnútornej a vonkajšej interpretácie počutého nielen $\mathrm{v}$ čase prijímania informácie, ale aj v určitom časovom odstupe. Ide o požiadavku aktívneho zapojenia ostatných psychických procesov, najmä pamäte, myslenia a obrazotvornosti do komunikačného procesu. Poslednú fázu označuje autorka ako fázu reakcie, ktorá obsahuje psychickú dispozíciu a zručnost' komunikátora použit' empatiu, asertivitu a persuáziu.

Uvedené požiadavky je potrebné rešpektovat' vo všetkých formách interpersonálnej komunikácie. V manažmente vzdelávania je vel'mi dôležitá a častá telefonická komunikácia, či vedenie pracovných porád. Čo je ciel’om telefonickej komunikácie a aké výhody ponúka? To sú otázky, ktoré neodmyslitel'ne patria k práci každého manažéra, v našom prípade riaditel'a školy. Výhodou efektívnej telefonickej komunikácie je, že umožňuje riaditel'ovi školy získat' dôveru a vytvorit' kladné vzt'ahy so súčasnými a potenciálnymi zákazníkmi školy, tiež umožňuje šetrit' čas a tým aj finančné prostriedky. Kombináciu e-mailu a písomnej korešpondencie s telefonátmi často nahrádzajú osobné kontakty, ktoré sú v niektorých prípadoch časovo náročné a nákladné. Telefón, resp. telefonát umožňuje riaditelovi efektívnu spoluprácu, ktorá nasleduje po osobných stretnutiach s externými spolupracovníkmi školy, sponzormi, predstavitel'mi nadriadených inštitúcií, či pri kontaktoch so zákazníkmi školy. Krátka telefonická komunikácia je spravidla efektívnejšia. Pomocníkom pri regulácii dížky hovoru je zobrazovanie času na displeji telefónneho prístroja, ktorý je programovatel'ný. Bežný telefonický rozhovor by mal trvat' podl'a odborníkov maximálne $4 \div 6$ minút, pri čom najčastejšími príčinami neprimerane dlhých a neefektívnych hovorov sú: neexistencia vlastného ciel’a; chýbajúca štruktúra hovoru; nesystematický postup; zbytočné opakovanie sa; nedorozumenie a absencia stručného zhrnutia výsledkov. (Backwinkel - Sturtz, 2005). Mnohí riadiaci zamestnanci majú problém ukončit telefonickú komunikáciu, čím strácajú čas na plnenie d'alších dôležitých úloh. Z uvedeného dôvodu odporúča (Uhlig, 2008) dodržat' nasledovné pravidlá: používat' krátke vyjadrenia, resp. uprednostňovat' jednoduché vety pred zloženými súvetiami; koncentrovat' sa na podstatu hovoru a predovšetkým na strategické ciele; v prípade, že riaditel' nemá k dispozícii dostatok vecných argumentov na vyriešenie problému, mal by si dohodnút' spätné zavolanie použitím nasledovných fráz: „Ujasním si to a zavolám Vám o tridsat' minút naspät'.“ „Na akom telefonickom čísle Vás môžem zastihnút?" a pod. Predchádzajúce informácie dopĺname o fázy úspešného telefonovania, ktoré obsahujú uvedený priebeh a štruktúru telefonátu. Považujeme ich za prospešných pomocníkov v prípade, ked' sú telefonáty cielene naplánované, uskutočnené a dodatočne korigované (Knoblauch, Woltje, 2006). Niektoré fázy sú v praxi opomínané. Dôsledkom sú nespokojní telefonickí partneri, nedorozumenia, zbytočne dlhé telefonáty, vyššie náklady a v extrémnych prípadoch ukončenie partnerských vzt'ahov. Mnohí účastníci telefonickej komunikácie si neuvedomujú dôležitost' piatich fáz profesionálneho telefonovania, ktorými sú: 1. Priatel'ský začiatok rozhovoru. 2. Profesionálna analýza problému. 3. Potvrdenie informácií (parafrázovanie). 4. Riešenie. 5. Ukončenie hovoru. (Ciglerova, 2002). Prvá fáza: Priatel'ský začiatok hovoru by sa mal niest' vo význame, že prvý dojem je rozhodujúci, posledný pretrváva. Začiatok a koniec telefonátu sú hlavnými determinantmi úspechu celého rozhovoru. Prvých dvadsat' sekúnd často rozhodne, či 
bude komunikácia prebiehat' $\mathrm{v}$ pozitívnej alebo negatívnej atmosfére. Podla skúseností je negatívny prvý dojem počas d'alšieho telefonátu len t'ažko napravitel'ný. Partnerovi je potrebné poskytnút' dostatok času na to, aby v pokoji vyjadril svoje priania a žiadost'. V tejto fáze je dôležité aktívne počúvanie a zaznamenanie si najdôležitejších detailov (približne 60 až 90 sekúnd), čím riaditel' školy získa solídny základ pre d’alší priebeh hovoru. Pomôckou sú hodiny na displeji telefónneho prístroja, ktoré objektívne zobrazujú čas trvania hovoru. Na konci prvej fázy by mal riaditel' prevziat vedenie hovoru. Toto najl'ahšie dosiahne využitím otvorených otázok, ktoré ho automaticky prevedú do druhej fázy komunikácie. Na začiatku hovoru sú obzvlášt' dôležité: profesionálna formulácia ohlásenia; priatel'ský a angažovaný hlas; ,úsmev“ pri telefonovaní; vytvorenie príjemnej atmosféry hovoru; ujasnenie si s kým hovoríme; vytvorenie dôvery a vyžarovanie pokoja; vytvorenie kompetencie vyjadrovania sa angažovaným spôsobom; primerané tempo vyjadrovania sa; vyjadrovanie záujmu zmenenou intonáciou hlasu; aktívne počúvanie a písomné poznámky. Je vhodné, ak je volajúci počas hovoru minimálne raz oslovený menom. V druhej fáze: Profesionálna analýza problému má riaditel' $\mathrm{k}$ dispozícii dôležité informácie, na základe ktorých si vyjasní d’alšie detaily. Je vhodné použit' otázky, ciel'om ktorých je prejavit' záujem, zistit' d'alšie dôležité detaily a získat' čas na návrh riešenia. K tomuto účelu je možné použit' techniku dotazovania, resp. opytovania. Kvalita druhej fázy závisí od rešpektovania nasledovných odporúčaní: správne pochopenie požiadavky; odpoved' na otázky: Kedy? Kde? Kto? Prečo? Ako? Kol'ko? Do kedy?; rozhovor nemôže mat' charakter výsluchu a d'alšie. Dôsledným rešpektovaním požiadaviek na druhú fázu telefonovania sa obmedzujú nepotrebné straty času a zhoršenie atmosféry počas telefonovania.

$\mathrm{Na}$ začiatku tretej fázy: Potvrdenie informácií (parafrázovanie) je potrebné ujasnenie najdôležitejších informácií. Vo väčšine telefonickej komunikácie totiž táto fáza chýba, pri čom sa často priamo prechádza od analýzy problému k fáze otázok zameraných na riešenie. To vedie $\mathrm{k}$ nedorozumeniam, lebo obaja partneri môžu nadobudnút' dojem, že každý hovorí o niečom inom. Z uvedeného dôvodu je potrebné v tejto fáze krátko zhrnút' podstatu žiadosti. Formulácie typu: „Rozumel som vám správne, že...?“ alebo „Ide vám teda o ...“ signalizuje volajúcemu, že ho riaditel' školy pozorne počúval a jeho žiadosti sa snaží porozumiet'. Tým sa získa pevná základňa pre d’alší priebeh hovoru. V štvrtej fáze: Riešenie, ak riaditel’ školy získa aktívnu odpoved' „áno“ môže prejst' k riešeniu žiadosti. Spravidla má tri možnosti: problém vyriešit' hned' a sám; vyjasnit' si žiadost' a zavolat' spät' neskôr a prepojit' hovor na kompetentného zamestnanca školy. V prípade okamžitého vyriešenia žiadosti (problému) je potrebné sa sústredit' na tieto podstatné požiadavky; používat' krátke a jednoduché vety; obmedzit' použitie cudzích slov a odborných termínov; neustále viest' rozhovor; koncentrovat' sa na užitočnost' riešenia; zdôrazňovat' výhody daného riešenia pre volajúceho; nepoužívat' nefunkčné frázy a vyplňujúce slová; používat' pozitívne formulácie. V piatej fáze: Ukončenie hovoru už volajúci nekladie d'alšie otázky, ale sumarizuje dôležité aspekty riešenia problému nasledovne: krátke zhrnutie najdôležitejších informácií; doladenie dôležitých údajov; informácia o adrese, emailovom kontakte, telefónnom čísle, alebo o bankovom spojení; verbalizácia navrhnutého riešenia; vyžiadanie si aktívneho súhlasu volajúceho s navrhnutým riešením. Ak volajúci vyjadril súhlas odpoved’ou „áno“, potom je možné hovor ukončit'. Pokial’ odpovie „nie“ alebo ešte so svojim súhlasom váha, je nutné sa vrátit’ spät’ k štvrtej fáze. Znamená to, že navrhnuté riešenie nepôsobí presvedčivo.

Dalšou významnou formou riadenia školy, ktorá si vyžaduje kompetentnú komunikáciu, je pracovná porada. Existuje niekol'ko publikácií, ktoré sa venujú ciel'om porady, ich dížke a d'alším kritériám. Menej je tých, ktoré sa zameriavajú na analýzu vhodných výrazových komunikačných prostriedkov tak, aby boli prínosom nielen pre vedenie školy, ale aj pre zamestnancov. Vyššie uvedené princípy Rogersovej teórie komunikácie založenej na rešpektovaní autentickosti osobnosti, 
empatickom prístupe a kongruencii je potrebné uplatňovat' tak, aby sa docielili nasledovné efekty. (Veber et al, 2002). Jednotlivé charakteristiky sú aplikované na školskú riadiacu prax. Zamestnanci si na porade majú možnost' uvedomit' svoje vlastné postavenie v pracovnom kolektíve školy. Porady s členmi učitel'ského zboru poskytujú priestor na vytvorenie tímov a upevňovanie participatívneho ducha školy. Riaditel'ovi porady umožňujú prejavit' svoje komunikačné schopnosti, vybudovat' si prirodzenú autoritu, upevnit' svoje postavenie. Zamestnanci sú osobou riaditel'a pozitívne motivovaní, pokial' sú presvedčení o jeho kompetentnosti a odbornosti (Haskova et al., 2019). Porada stimuluje kolektív ku konkrétnym záväzným ciel'om, pretože sú ideálnym fórom pre prezentáciu ciel'ov a prostriedkov $\mathrm{k}$ ich dosiahnutiu. Porada je faktor synergie, pretože všetci jej účastníci ponúkajú a zdiel'ajú svoje skúsenosti, poznatky, talent a predstavivost'.

V komunikácii nielen na pracovných poradách, ale aj pri riešení konfliktov a d'alších činnostiach manažéra je potrebná autokontrola komuniké nielen po obsahovej stránke, ale aj z pohl'adu jeho verbalizácie, používania nonverbálnych znakov a paralingvistických prejavov. (Hupkova, 2011) upozorňuje na nasledovné komunikačné zlozvyky a chyby pri hovorení. Nesúlad slovného a mimoslovného prejavu (dvojitá väzba), čo znamená, že prejav obsahuje inú informáciu, ako možno pozorovat' z mimoslovného prejavu napríklad v mimike, gestách, postoji, či tóne hlasu. Zovšeobecňovanie a preháňanie, čo sa prejavuje v tendencii hodnotit' situáciu neprimerane, nadnesením negatívnych zážitkov a prehliadnutím pozitívneho aspektu. Nedostatok konkrétnosti v reči sa prejavuje nejednoznačnou formuláciou, čo má za následok nezrozumitel'nost' obsahu informácie. Tým sa poslucháčovi poskytuje vel'ký priestor pre rôzny výklad, čo pravdepodobne spôsobí nedorozumenie. Neúprimnost' znamená, že manažér vedome skresl'uje alebo predstiera svoje emócie za účelom osobného prospechu, manipulácie $\mathrm{s}$ inými, či v dôsledku strachu z úprimnosti. V praxi sa často vyskytuje aj d’alší zlozvyk, ktorým je pripisovanie úmyslu tomu, čo druhý hovorí alebo robí v zmysle skrytého úmyslu. Únikom od témy autorka nazvala tendenciu odbočovat' počas rozhovoru od hlavnej témy. Tejto chyby sa niektorí riaditelia škôl dopúšt'ajú pomerne často, čo môže mat' za následok nevyriešenie problému a neefektívny časový manažment. (Pisonova, 2012). Nelogické afektívne odpovede: prehnaná afektívna reakcia na podnet, použivanie expresívnych výrazov. V tomto prípade býva možnou príčinou emočná nestabilita riaditel'a, ktorá je väčšinou vnímaná zamestnancami školy odmietavo. Aj nepriame vyjadrovanie citov oklukou sa vyskytuje v komunikácii manažérov škôl. Ide o neúprimnú komunikáciu, ktorá je v rozpore s ich prežívaním.

\section{Záver}

Umenie komunikovat' predstavuje v súčasnosti dôležitú a nenahraditel'nú kompetenciu školského manažéra (Haskova, 2011; 2012). Je to jeden z jeho hlavných pracovných nástrojov, ktorý používa každý deň v kontakte $\mathrm{s}$ pedagógmi, prevádzkovými zamestnancami, zriad'ovatel’om, zákonnými zástupcami žiakov, ale aj s verejnost'ou. Je zrejmé, že schopnost' adekvátnej komunikácie v kontakte s vyššie uvedenými ciel'ovými skupinami si bude vyžadovat' použitie viacerých komunikačných prostriedkov a stratégií. Predmetný príspevok poukazuje iba na niektoré aspekty manažérskej komunikácie a zároveň apeluje na tých, v ktorých kompetencii je príprava a d’alšie vzdelávanie školských manažérov, aby jej venovali náležitejšiu pozornost'. Komunikácia sa totiž stáva súčast'ou všetkých manažérskych funkcií, ktorými sú plánovanie, organizovanie, vedenie l'udí, rozhodovanie či kontrola (Pisonova et al., 2017). Ich obsah je možné implementovat' do praxe iba prostredníctvom profesionálnej komunikácie, ktorá je mostíkom k permanentnému rozvoju a prosperite školy prostredníctvom vytvárania a udržiavania kvalitných medzil'udských vzt'ahov. 


\section{Bibliographic references}

ARMSTRONG, M. - STEPHENS, T. 2008. Management a leadership. Praha: Grada Publishing. ISBN 9788024721774.

ARMSTRONG, M. 2015. Rizeni lidskych zdroju: Moderni pojeti a prístupy. Praha: Grada Publishing. ISBN 9788024752587.

BACKWINKEL, H. - STURTZ, P. 2005. Telefonujte profesionálne. Praha: Grada Publishing. ISBN 8024713977.

BORG, J. 2007. Umeni presvedcive komunikace. Praha: Grada Publishing. ISBN 978 8024719719.

CAUNT, J. 2007. Time management. Brno: Computer Press. ISBN 9788025115381

CIGLEROVA, C. R. Rokovat spravne sekretarky. Praha: Grada Publishing. 80247 0448 X.

DONNELlY, J. H. - GIBSON, J. L. - IVANCEVICH, J., M. 1997. Management. Praha: Grada Publishing. ISBN 8071694223.

DUCHOVICOVA, J. - FENYVESIOVA, L. 2019. Applying of strategies of critical and creative thinking by teachers according to the teaching subject and degree od education. In: AD ALTA: Journal of Interdisciplinary Research, vol. 9, n. 1 (2019), pp. 49 - 55. ISSN 24646733.

HASKOVA, A. - PISONOVA, M. 2019. The competences of school leaders and the impact of school reform on their positions. In: Progress in education, vol. 59. New York: Nova Science Publisher, 2019. ISBN 978-1-53615-368-2. ISSN 1535-4806.

HASKOVA, A. 2019. Analysis of current changes regarding head teachers role and position in Slovakia. In: ICERI 2019 Proceedings, pp. $11632-11639$. Seville: IATED Academy, 2019. ISBN 9788409 14755 7. ISSN 23401095.

HASKOVA, A. 2012. Osobnost riaditela skoly v kontexte výsledkov narodnych a medzinarodnych vyskumov. In: Sbornik prispevku $\mathrm{z}$ mezinarodni konference skolskeho managementu, pp. 73 - 81. Praha (CZ): CSM PF UK, 2012. ISBN 97880 72906024.

HASKOVA, A. 2011. School leaders' competencies: results of research carried out in Slovakia. In: Barath, T. - Szabo M. (ed.): Does Leadership Matter: Implications for Leadership Development and the School as a Learning Organisation. Szeged (HU): HUNSEM, University of Szeged, pp. 242-253. ISBN 9789633061114.

HASKOVA, A. - BITTEROVA, M. 2018. School autonomy and school leadership: Case study of school operation in Slovakia. In: Problems of education in the $21 \mathrm{st}$ century, vol. 76, n. 3, 2018, pp. 299-308. ISSN 18227864.

HUPKOVA, M. 2011. Rozvíjanie sociálnych spôsobilostí v pomáhajúcich profesiách. Bratislava: Iris. ISBN 9788089256617.

IBRAGIMOVA, T. - SARGAZIN, Z. - ZHANZHUMENOVA, A. - AKCHIN, A. FEDOSEENKO, K. 2020. The Issues of Influence of Moral Denotions to Self-esteem of People. In: Slavonic Pedagogical Studies Journal, Vol. 9, n. 1, pp. 86-92. eISSN 1339-9055, ISSN 1339-8660.;

KNOBLAUCH, J. - WOLTJE, H. 2006. Time management. Praha: Grada Publishing. ISBN $802471440 \mathrm{X}$.

KONVIT, M. - JAKUBIKOVA, B. 2008. Teoria komunikacie. Zilina: Poradca. ISBN 9788089213436.

MAJTAN, M. et al. 2003. Manazment. Bratislava: Sprint. ISBN 8089085172.

MAJTAN, M. et al. 2016. Manazment. Bratislava: Sprint dva. ISBN 978808971027 0 .

MIKULASTIK, M. 2015. Manazerska psychologie. Praha: Grada Publishing, pp. 95120. ISBN 9788024798353.

MIKULASTIK, M. 2003. Komunikačni dovednosti v praxi. Praha: Grada Publishing. ISBN 8024706504. 
MIKULASTIK, M. 2006. Komunikacni dovednosti v praxi. Praha: Grada Publishing. ISBN 8024706504.

MCQUAIL, D. 2007. Uvod do teorie masove komunikace. Praha: Portal. ISBN 8073673383.

PETRASOVA, M. A. - STEPANEK, Z. - PRAUSOVA, I. 2014. Mentorink - forma podpory nove generace. Praha: Portál. ISBN 9788026206255.

PETROVA, G. - KOZAROVA, N. 2018. The involvement of neuro-linguistics and mind mapping in the development of a holistic perception of language education. In: Journal of Language and Cultural Education, vol. 6, n. 2, 2018, pp. 117. ISSN 1339 4584.

PETRUFOVA, M. - KURHAJCOVA, L. - BELAN, L. - SULC, P. -NEKORANEC, J. 2009. Manazerska komunikacia:(vysokoskolska ucebnica). 1. vyd. Liptovský Mikulas: Akademia ozbrojenych sil generala Milana Rastislava Stefanika. ISBN 978 8080403706 .

PISONOVA, M. et al. 2017. Skolsky manazment - terminologicky a vykladovy slovnik. Bratislava: Wolters Kluwer. ISBN 9788081686603.

PISONOVA, M. 2011. Kompetencny profil manazera vychovnovzdelavacej inštitucie. Bratislava: Iura Edition. ISBN 9788080784027.

PISONOVA, M. 2012. Osobnostny rozvoj riaditela skoly - vychodiska a determinanty. Bratislava: Iura Edition. ISBN 9788080784706.

PISONOVA, M. a kol. 2014. Skolský manažment pre studijne odbory ucitelstva a pripravu veducich pedagogickych zamestnancov. Bratislava: Univerzita Komenskeho. ISBN 9788022336215.

PITONAKOVA, S. 2012. Public relations and journalism. In: Komunikácie, vol. 14, n. 1, pp. 49-54. ISSN 1335-4205.

PUSHKAREV, Y. V. - PUSHKAREVA, E. A. 2017. The concept of intellectual potential development: the main dimensions and bases within the context of lifelong education (review). In: Novosibirsk State Pedagogical University Bulletin, n. 3, pp. 140-156. DOI: http://dx.doi.org/10.15293/2226 3365.1703.09.

ROBBINS, H. A. 1992. How to Speak and Listen Effectivelly. New York: Amacom.

RODRIGUEZ, D. - BUSCO, C. - FLORES, R. 2015. Information technology within society's evolution. In: Technology in Society, vol. 40, pp. 64-72. DOI: https://doi.org/10.1016/j.techsoc.2014.08.006 SHIELDS.

ROGERS, C. R. 1999. O osobnej moci. Bratislava: Persona. ISBN 8096798014.

ROGERS, C. R. 1998. Zpusob byti. Praha: Portál. ISBN 8071782335.

SEDLAK, M. 2007. Manazment. Bratislava: Iura Edition. ISBN 9788080781330.

SOLLAROVA, E. 2005. Aplikacie PCA (pristupu zameraneho na cloveka) v poradenstve a v organizacii. Bratislava: Ikar. ISBN 8055109613.

SVANCARA, J. 1999. Terminologie a dokumentace psychologickych praci. Brno: Masarykova univerzita. ISBN 8021020296.

SVETLIK, J. 1996. Marketing skoly. Zlin: Copyright. ISBN 8090220088.

SVANCARA, J. 1999. Terminologie a dokumentace psychologickych praci. Brno: Masarykova univerzita. ISBN 8021020296.

SULER, O. 2002. Zladate sve manazerske role? Praha: Computer Press. ISBN 80 72267027.

SZARKOVA, M. 1996. Manazerska psychologia. Bratislava: KARTPRINT. ISBN 80 88870011.

SZARKOVA, M. 2018. Komunikacia v manazmente. Bratislava: Wolters Kluwer. ISBN 9788075981844.

UHLIG, B. 2008. Time management. Stante se panem sveho casu. Praha: Grada Publishing, pp. 69-70. ISBN 9788024722618.

VEBER, J. et al. 2002. Management. Zaklady, prosperita, globalizace. Praha: Management Press. ISBN 8072610295.

XLinguae, Volume 13 Issue 3, June 2020, ISSN 1337-8384, ISSN 2453-711X 
Words: 6915

Characters: 51795 (28,80 standard pages)

Prof. PaedDr. Mária Pisoňová, PhD.

Department of Pedagogy

Faculty of Education

Constantine the Philosopher University

Nitra

Slovakia

mpisonova@ukf.sk

Assoc. Prof. PaedDr. Peter Brečka, PhD.

Department of Technology and Information Technologies

Faculty of Education

Constantine the Philosopher University

Nitra

Slovakia

pbrecka@ukf.sk

Assoc. Prof. Ing. Viera Papcunová, PhD.

Department of Economics and Management

Faculty of Natural Sciences

Constantine the Philosopher University

Nitra

Slovakia

vpapcunova@ukf.sk

Mgr. Barbora Jaslovská, PhD.

Department of Education and Social Pedagogy

Institute of Educational Studies

Faculty of Education

Comenius University

Bratislava

Slovakia

jaslovska@fedu.uniba.sk 